\title{
What Does it Mean to Justify Basic Rights?
}

\author{
Reply to Düwell, Newey, Rummens and Valentini*
}

Rainer Forst

It is a great privilege to have four colleagues whose work I admire as discussants for my paper on basic rights - and a challenge I very much appreciate. Marcus Düwell, Glen Newey, Stefan Rummens, and Laura Valentini pose tough questions for my approach, quite a few of which refer to the broader framework of my theory of justification that the argument for basic rights I present here relies upon. I will do my best to respond to their questions, though at times I fear I need to be much briefer than the topic at issue calls for. But I hope this is permissible for the sake of a lively discussion. Though the concerns of the questions raised overlap to some extent, I prefer to respond to each paper individually, with the exception of a final response to a question most of them pose, namely that of the extension of the community of rights holders. I order the response such that a coherent overall argument develops (or so I hope), from conceptual to a number of substantive issues.

\section{The dialectics of basic rights: actual and hypothetical justification}

With the conceptual clarity that is typical of her work, Laura Valentini discusses the virtues and vices of my approach, and it is with great pleasure that I read her sympathetic account of the former as well as her probing critique of the latter. I will do my best to show that a sufficiently dialectical reading of my account avoids these vices.

Valentini starts with a discussion of the concept of basic rights and the criteria for a successful justification of such rights. But already here we should take note of important differences. We both think of basic rights as claim-rights in a Hohfeldian or Feinbergian way (as I explain in the second section of my article) but Valentini regards the rights relation as one between a right-holder $\mathrm{A}$ and a duty-bearer B on a purely moral level, and affirms that 'basic rights are those that any social system - e.g., any state - must honour to be minimally morally acceptable. ${ }^{1}$ I think this way of understanding basic rights neither does justice to the conceptual relation between moral and legal rights that we need to take into account nor does it express the notion of basic rights in a sufficient way. Basic rights are not only rights $A$ has against $B$ in a moral sense; they are rights that

* Many thanks to Nate Adams for a critical reading of this text and to Paul Kindermann for his help in preparing the final version.

1 Laura Valentini, 'On the Justification of Basic Rights', Netherlands Journal of Legal Philosophy 45(3), 53. 
one has the right to have and be secured in a normative order one is part of in the right way. In other words, they are not just rights one has against others as individuals but also rights which imply that a political public authority is constituted in a particular way so that these rights become legally secured and materialized. More than that, if we properly understand the idea of basic rights, we see that the moral authority of being a rights-bearer travels to the legal authority (or normative power) of persons to have basic rights and to the political authority of persons to have standing as someone who co-determines the normative order to which they are subject. This is why I explain the concept of basic rights not just with reference to Hohfeld and Feinberg but also with reference to Jellinek and the status activus of citizens. This already marks a difference to liberal approaches like Valentini's, which focus on a moral justification for basic rights that is insufficiently combined with their legal and political character. After all, what we are looking for is a moral justification for legal rights within a properly formed political normative order. And if we unpack this relation between morality, law, and democracy in the right (dialectical) way, we are on the path towards the best account of such rights. They are not rights simply to be 'mirrored'2 in a political system but rights to be part of a basic structure of justification in which members of a normative order actively co-determine these rights.

I take basic rights to be reciprocally and generally non-deniable claims on others (agents or institutions) that they should do or refrain from doing certain things determined by the content of these rights. They are called basic because they define the standing of persons as full members of a normative order protecting them from severe forms of legal, political and social domination. The latter property is important, otherwise the notion of basic rights gets too broad and unfocused, as if all rights based on the right to justification were basic rights (a point I will come back to in responding to Newey's concerns). In my paper, therefore, I start from what I take to be a plausible definition of basic rights and unpack what it implies with respect to the ground and function of these rights. So I claim that my account provides the best conceptual analysis of the notion of basic rights as well as the best normative foundation for basic rights, given the legal and political character and function of such rights. Further, my theory is in tune with the best account of the historical and political practice of fighting for and materializing such rights. For I take the struggle for rights to be an emancipatory struggle, and an unfinished one, as neither in current democracies nor in non-democratic regimes have we managed to establish such a status of non-domination. That is why I consider my approach to be a critical theory, as it is in accord with the best account of basic rights as both a reality and an aspiration of those who still suffer from domination in one or the other way, be it economic exploitation or legal discrimination.

Essentially, the main reason why I take my approach to be superior to others is that it is a reflexive theory which properly unpacks what it means to say that basic 
rights are justifiable (or non-deniable, in the stronger version) claims between normative equals - reconstructing a unified whole out of the many aspects the word 'justifiable' has in this formulation. In the realm of theory, one important virtue is simplicity, and I take it that this ideal is reached if a theory is based on a single principle - that of justification - complex enough to cover all the aspects required for a theory of basic rights: from its moral ground to its justifiable content. If this can be achieved, I would even call such a theory elegant - an ideal I dare not claim to have met.

I am not sure whether the two criteria Valentini suggests for a good justification of basic rights fully capture all we need. According to her, such a justification has to 'fit with evidence,' i.e., 'fit our most strongly held convictions about basic rights,' and secondly, it has to 'account for and illuminate our most strongly held

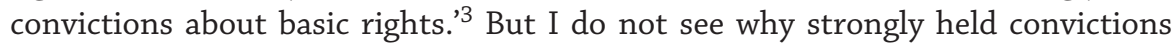
amount to a form of 'evidence' that could ground a theory of basic rights, for these convictions, though strongly held, could still be wrong. Nor do I see why the attempt to explain these convictions could not also be a critical-theoretical account that shows their ideological character, for example as we do when we criticize the libertarian conception of 'natural rights' to certain forms of private property - a strongly held conviction by many that a critical theory of basic rights ought to take issue with. So I beg to differ with respect to these criteria - after all, what we want is a theory of basic rights strong enough to correct strongly held convictions by, as I said, the best account of the concept of basic rights, their moral core, their legal and political character, and their historical function. Theory trumps conviction, if it can account for all that on the basis of principles which are not reasonable to reject. And that is where we enter the realm of the transcendental. But I will leave that for a later discussion with Newey and Düwell.

On Valentini's reading, my approach is 'procedural' rather than substantive, that is, not grounded 'in particular features of human beings' but rather 'in dialogic procedures. ${ }^{4}$ I am not sure I fully agree with this, for, to make another dialectical statement, the approach I favour is a substantive proceduralism, as it presupposes a moral notion of the person as a normative authority equal to all others and in fact not subject to any other normative authority than the norms which free and equal persons can reciprocally and generally justify, or rather what they cannot reject if they respect that status as equals. The basic standing as a moral authority equal to all others is what the traditional term of 'dignity' is meant to express that was and is often used in struggles for basic rights and in their declaration and constitutional form. That is where the Kantian groundwork of my theory that Valentini leaves aside comes in, and it is necessary to understand the difference to interest-based and will-based accounts of basic rights from that angle. Not fully taking into account the fundamental notion of a person with a right to be respected as an equal normative authority - or with equal dignity leads Valentini, I think, to a slightly contradictory view with respect to the inter-

3 Valentini, 'On the Justification of Basic Rights', 54.

4 Valentini, 'On the Justification of Basic Rights', 55. 
est theory of rights. For on the one hand, she seems to agree with me that the right to justification is fundamental when it comes to identify the interests that are reciprocally justifiable in grounding basic rights to non-domination ${ }^{5}$; yet on the other hand she argues that only by taking certain interests as basic can we know what free and equal persons could and should hypothetically agree to accept and protect. ${ }^{6}$ But this gets things (as I thought we agreed) the wrong way around: there are no interests with a certain normative weight prior to the standing of moral equals, and only the claims that are reciprocally and generally justifiable between such equals as claims to a standing of legal, political, and social nondomination are the claims that can lead to basic rights. Justifiability between equals is what counts, not some notion of essential interests. For persons have a claim to a status of dignity independent of the interests they have, and only on that basis can their interests count as justifiable claims.

This brings me to the important issue of the relation between actual and counterfactual justifiability that Valentini raises, which I am grateful to her for doing because that part of the theory might need some more explanation. Valentini is of course right to suggest that I try to combine both of these levels of justification, as I explain in the fourth section of the article, in a dialectical way that avoids the criticism she levels against one-dimensional actualist and hypothetical approaches. I call this dialectical because of the way both levels are related, for the one cannot do without the other. Obviously, a Kantian constructivist view cannot rest with an actualist conception of justification, for it needs to provide us with a critical distance towards the results of real political procedures of justification. So on the level that I call moral-political constructivism, we justify a set of basic rights in an abstract way that a justifiable normative order needs to secure and materialize - but, remember, in a mode of political justification among justificatory equals. Thus on the second, political-legal level of justification it is in democratic procedures where these abstract rights are sufficiently materialized that a collective discusses and determines what, say, the general right to political participation means concretely - from direct forms of democracy to council systems or representative systems with one or two or more groups of elected representatives. It is true that the latter procedure presupposes the former in order to be justifiable and lead to justifiable results, but that is not a vicious circle, it is just a reflection on what it means to respect others as legal, political and social equals in a scheme of democratic justification. We criticize every such scheme that violates basic rights either in its structural setup or in its decision outputs. But at the same time we affirm that the basic right to justification entails that no other system than that of democracy among equals can legitimately define what the basic rights of persons concretely mean. Again, we need to heed the distinction between a moral argument for basic rights and an argument for the legitimacy of legal rights as defined through a democratic normative order. The latter both pre- 
supposes and renders concretely the abstract moral set of basic rights defined on the counterfactual level.

With regard to that counterfactual level, I already pointed out my disagreement with the interests-first approach Valentini wants to hold onto. She also wonders why a hypothetical justification procedure could not result merely in a set of duties of the state to protect the "important interests' ${ }^{\text {' }}$ of persons. My answer to this is that if the justification procedure is set up in the right way, it will lead to a normative order that expresses the basic right to justification (and the duties that follow from it) in the right way - and that means that the normative authority to decide which rights and duties individuals justifiably have rests with them, collectively forming a political authority to determine their rights and duties in a democratic procedure of justification. The status activus has to remain in place. Remember that the idea of basic rights came into being in social struggles against undemocratic, illiberal, and feudal normative orders. As long as there are grounds for such struggles, the language of rights will be the political-legal language of individual dignity, the dignity of a law-giver and a rights-bearer - and the two form a necessary unity. If, however, the time comes for alternative social orders of justification beyond such struggles, the language of legal rights might become less important, yet the right to justification - or the non-deniable claim to participate in the determination of the normative order you are part of - will not. It will just lead to other social and political systems.

\section{Distinctions, connections and sources}

Stefan Rummens is a kindred discourse theorist whose work I think very highly of and always find challenging, especially when we differ about how to reconstruct the social world in terms of justification theory. He asks tough questions about the general structure of my argument and about the source(s) and substance of basic rights.

Rummens questions the relation between three distinctions that I make in my paper (and other works): that between the principles of constructivism and constructed norms, that between (the just discussed) moral and political construction and that between a direct and a more indirect argument for certain basic rights. Rummens thinks that these are not three different distinctions but one and the same, and I fear I disagree. But it is important to be clear on that, so Rummens's questions are very much to the point.

As he rightly points out, I follow Rawls and others in distinguishing two kinds of normativity in constructivism, that of the reconstructed principles and ideas of practical reason and that of the norms resulting from a procedure of construction, be it moral or legal-political. On my account, the first level consists of the principle of justification which says that norms have to be justified (or constructed) 
according to their inherent validity claim. And it is a reflection on what this means in a moral context of claims to reciprocal and universal validity that the idea of agents as equal moral authorities with a right to justification corresponds to this principle, as they are the agents who are governed by this principle and who govern their moral world of reasons and norms according to it. Thus the principles of justification and the agents of justification belong to the first level of normativity that we arrive at through a reflexive reconstruction of what it means to act with good moral reasons - i.e., we start from the practice of moral justification and work our way up to its principles and normative implications. We can also go one step further and phrase this by way of a transcendental argument, as this kind of reconstruction shows the conditions of the possibility of justifiable moral action and thus our place in the moral space of reasons as reason-givers and receivers of reasons - or, in Kantian language, as moral law-givers and subjects of the moral law at the same time. Transcendental reflection shows us who we are in the noumenal world of reasons - namely 'ultimate' moral authorities still bound by the principle of justification.

Based on such reflection, we distinguish the constructivist practice of justification of either moral or political-legal norms and the argument for basic rights applies, as I explained, to both levels, properly connected. Yet the reconstruction of the principle and the right to justification is different and prior to these constructivist procedures. They are different from the justification of basic moral norms as well as from the justification of political-legal norms; there is a grounding relation between the right to justification and basic moral norms but the two are not the same thing. What I call fundamental justice, to use the example of a basic framework for political and social justice that Rummens cites, ${ }^{8}$ is not on the same level as the principles of practical reason.

Finally, there is the important question about the distinction between two arguments for basic rights, both located at the moral-political level of construction, thus not coinciding with the distinction between (counterfactual) moral-political and legal-political constructivism in democratic procedures (which need to deserve the name 'democratic,' as I explained in response to Valentini). Rummens is right that reciprocity plays a role in both arguments for basic rights, thus I admit that the phrasing of the distinction is not terribly felicitous, yet I think that it is not the same role and that there still is a distinction between the argument for basic rights that are strictly required to secure the status of being a justificatory equal and rights that follow if we regard each other as justificatory equals and ask ourselves whether certain norms can be reciprocally and generally rejected or not. For example, a certain form of personal liberty is a status-implication of free and equal normative authorities recognizing each other as non-dominated equals, while a certain form of religious liberty is a reciprocity-based argument justified by the insight that imposing certain religious views or norms on others violates their equal standing as non-dominated equals. Both times the

8 Stefan Rummens, 'Two Sides of the Same Coin. Unpacking Rainer Forst's Basic Right to Justification', Netherlands Journal of Legal Philosophy 45(3), 43. 
results are basic rights, but the first argument is of a more direct nature - at least it seems to me that way. So I disagree with Rummens both when he says that the distinction is reducible to the one between the reflexive normativity and that of constructed norms or that of moral and political constructivism and when he says - which seems incompatible with these former claims - that the distinction is 'moot' ${ }^{\text {' }}$ and does not exist. I think it exists and cannot be reduced to the others.

The second point that Rummens raises goes back to a debate I take sides in among Habermas, Wellmer, Günther, Niesen and others whether a discoursetheoretical theory of basic rights can account for rights to personal autonomy in the sense of choosing your own ends. Other than some of these theorists, Rummens shares with me the view that the rights to public and the rights to private autonomy do not stem from two different sources but from one, namely the right to justification, yet he maintains, if I understand him correctly, that the right to justification itself is split with respect to these two aspects of autonomy. So they stem from one source but fall into 'two different but inseparable rights. ${ }^{10} \mathrm{I}$ am not sure we really differ here, at least on one reading of his critique which says that the right to justification grounds very different rights such as the right to political participation as well as the right to 'choose our own ends in our own private spheres. ${ }^{11}$ On that reading, we agree that the basis for the latter right is not some natural right to unconstrained liberty but the right to be the final authority in all the life choices that do not concern others in a way that calls for moral or legal constraints - i.e., the right to a reciprocally and generally justifiable form of personal liberty, as my Kantian scheme has it.

But on another reading of his critique we do differ, namely when he says that the right to justification is one thing and the right to choose our own ends another, not reducible 'to our authority as co-authors of norms' ${ }^{12}$ for if that were true, they would stem from two different sources such as two concepts of liberty or some such. His argument that there are two forms of authority in play - over your own life and over mutually justifiable norms ${ }^{13}$ suggests this, for saying that these two authorities are not reducible to one implies two sources, though he denies this. I do not think they do, as to be a free and equal normative authority to others both implies co-authorship of norms and the freedom to be protected from unjustifiable interference into your personal concerns. I take this to be the (Kantian) lesson of overcoming certain forms of political and personal domination in modern times, which Rummens refers to at the end of his contribution.

9 Rummens, 'Two Sides of the Same Coin. Unpacking Rainer Forst's Basic Right to Justification', 45.

10 Rummens, 'Two Sides of the Same Coin. Unpacking Rainer Forst's Basic Right to Justification', 47.

11 Rummens, 'Two Sides of the Same Coin. Unpacking Rainer Forst's Basic Right to Justification', 47.

12 Rummens, 'Two Sides of the Same Coin. Unpacking Rainer Forst's Basic Right to Justification', 50.

13 Rummens, 'Two Sides of the Same Coin. Unpacking Rainer Forst's Basic Right to Justification', 50. 


\section{The realm of reasons: Hobbesian or Kantian?}

In the contemporary landscape of political philosophy, one cannot find a more thorough, thoughtful, and imaginative sceptic about high-flying normative approaches than Glen Newey. If anyone could succeed in making a convincing rational claim that the space of reasons is closer to the Hobbesian state of nature (if not ordered by sovereign will) rather than to a Kantian noumenal realm (ideally) ordered by principles of reason, it would be him. To be clear, I would never doubt that the existing social space of reasons is populated by all kinds of power strategies and ideological hegemonies, so that is not where our disagreement lies. Instead, we differ about how to reconstruct the principles used to criticize such states of affairs. For him, these are essentially political questions to be decided by sovereign power; for me, these are questions of justification guided by principles of reason.

In the beginning of his critique, Newey rightly points to the plethora of grounding formulations referring to the dignity of autonomous persons as law-givers, their right to justification according to the principle of justification and its meaning in moral contexts, and the respect owed to moral persons with the status of a normative authority equal to all others. He is right to say that these formulations neither coincide nor concur, ${ }^{14}$ as they refer to different aspects of the Kantian groundwork I reconstruct in my work which, as I hope, all cohere. They cohere by being part of a normative account of what we are rationally committed to as agents of justification.

Newey rightly asks how the fundamental right to justification is related to basic rights as they appear in legal documents. And it is important to stress that the right to justification is a moral right only in a moral context where others are affected by one's actions in a morally relevant way - thus from the start my view has a 'triviality threshold' 15 built into it, to mention a concern that Newey raises throughout his contribution. This already reduces the duties that are implied by this right, for in matters which do not concern others in a morally relevant way, I owe no reciprocally and generally non-rejectable justification to them. In practice, the question of whether, say, buying a newspaper or living according to a certain religion affects others in a morally relevant way can be contested, for the newspaper might be a notorious right-wing paper that justifies violence towards other persons and the way I live my religion might entail the violation of the basic standing of others as equals. The history of toleration, which both Newey and I have studied, shows itself to be one of redefining the space of actions that are seen as morally objectionable and rejectable. But that kind of contestability does not deny the focus of my thesis about the moral right to justification being restricted to moral contexts.

15 Newey, 'The Justification of Basic Rights. A Response to Forst', 66. 
Thus Newey's concerns about 'pan-justificationism'16 stem, for the most part, from an overly broad interpretation of what the thesis about the right to justification entails - though these really are questions about the larger framework of my argument rather than about the issues covered in this paper. As I explained in Contexts of Justice ${ }^{17}$ and The Right to Justification, ${ }^{18}$ we must distinguish rights and duties of justification according to the contexts in which claims are raised, and it is only in moral contexts and those legal-political contexts where morally relevant issues and claims are raised (and the context of basic rights is of such a kind) that the right to justification as a right to reciprocal and general justification is a moral right. In many contexts of social life where no moral issues are concerned, other justification obligations come with certain actions or statements - and some actions, like 'humming' ${ }^{19}$ might need no justification at all. And as far as basic rights are concerned, there are good reasons for the justification of a right to privacy which protects one from unjustified demands for justification (I briefly mention this in my paper at the end of section 4).

Beyond that first restriction of the right to justification to moral contexts where there is a perfect duty of justification, it is important to stress that not all justifiable moral claims translate into basic rights in the sense at issue in the paper. Thus Newey's conjecture that I identify basic rights 'with the set of obligations that are generated directly or vicariously by the right to justification' ${ }^{20}$ is wrong, as there are a number of moral obligations (or better: duties) that do not strictly relate to a basic legal right. For example, there is the moral duty to tell the truth but there is no general basic legal right to always be told the truth. Also, there are a number of imperfect duties that follow from regarding others as normative equals but there are no particular rights that correspond to them. To understand my approach to basic rights, as morally justified legal rights, it is important to recognize what Newey neglects, namely that basic rights are a subset of morally justified rights: those that protect members of a normative order from severe forms of legal, political and social domination. That is how this subset of rights is determined, and, as noted above, the duties that this implies are twofold, namely duties of persons to respect these rights and duties of a political authority to see to it that these rights are properly determined and institutionalized.

As far as the issues of the discretionary character of rights and their inalienability are concerned, I agree with Newey about distinguishing the ground and the content of basic rights. Given the ground of being an equal normative authority to others and the basic rights to non-domination that can be established on that basis, there is room for discretion with respect to using these rights, respecting

16 Newey, 'The Justification of Basic Rights. A Response to Forst', 70.

17 Rainer Forst, Contexts of Justice: Political Philosophy beyond Liberalism and Communitarianism, trans. John M. Farrel (Berkeley: University of California Press, 2002).

18 Rainer Forst, The Right to Justification: Elements of a Constructivist Theory of Justice, trans. J. Flynn (New York: Columbia University Press, 2012).

19 Newey, 'The Justification of Basic Rights. A Response to Forst', 66.

20 Newey, 'The Justification of Basic Rights. A Response to Forst', 67. 
these rights, and institutionalizing them. And Newey surely agrees that for the many cases of conflict about differing judgments of discretion, a normative order has to provide practices and institutions of justification where these conflicts can be solved legally. Furthermore, agreeing to terms of employment which oblige you to certain forms of secrecy of course does not mean that you waive your right to free speech which you can always use, even if that entails breaching the employment contract. Agreeing to not use a basic right temporarily and in certain contexts can never mean permanently waiving that right. It is always there for you to use (or reuse); the normative order granting these rights will protect you if you do so and it will not accept you waiving them completely or once and for all.

Newey challenges the Kantian non-domination view by suggesting that it itself is committing the same crime, i.e., imposing a non-generalizable view on others. It seems to me, however, that this criticism will itself be based on the discursive right (of non-Kantians) to non-domination or non-imposition of a view that cannot be generalized, and thus the critique presupposes what it criticizes. But it is also based on a premise I do not hold, as I do not say that the principle of discursive justification and non-domination is in fact generally shared. What I say is that I do not see the reasons against the validity of that principle as a principle of practical reason; the concrete ways in which this principle is applied may be faulty and the object of justifiable critique, yet the principle that norms that are imposed on all reciprocally and generally ought to be justifiable with reasons of reciprocity and generality will then be the basis of that very critique, as it is in Newey's case, I think.

Newey is on firmer ground with respect to my view when he presents the Kantian interpretation of it, saying that a right to justification is violated when someone is treated as a mere means and not as an end in him- or herself. But then it is not correct to say that the right to justification is 'created' ${ }^{21}$ in that very moment, for being treated as an end means being treated according to reciprocally and generally justifiable norms such that one could, as Kant says, 'agree to my way of behaving toward him, and so himself contain the end of this action.'22 The right to justification has already been violated when someone disrespects another and does not treat him or her as a moral equal, for then he or she is subjected to unjustifiable ways of acting. Thus instrumentalizing another is the violation of his right to be treated as a justificatory equal; there is no explanatory order that takes wrongness as a quality apart from unjustifiability between equals. I think Newey says that much when he explains that saying that an act is wrong is shown by 'the fact that it cannot be justified.' 23 That is what I mean.

What, finally, does the notion of the right to justification add to the idea that we should not treat others wrongly? Apart from expressing the central moral idea

21 Newey, 'The Justification of Basic Rights. A Response to Forst', 71.

22 Immanuel Kant, Groundwork of the Metaphysics of Morals, trans. Mary Gregor (Cambridge: Cambridge University Press, 1998), 38 (Ac 4:429f.).

23 Newey, 'The Justification of Basic Rights. A Response to Forst', 72. 
that persons are equal authorities in the space of normative justifications, it gives you a criterion for 'wrongly' that avoids reified and paternalistic normative definitions of what 'right' and 'wrong' mean and therefore leaves room for a moral critique of false morality or for what I would call 'moralism,' i.e., the use of reified and unfounded moral standards. I am not sure which definition of 'moralists' 24 Newey has in mind, but I assume something like this to be in play if that is meant as a term of critique. In any case, what we want is a critical morality and not one that imposes and reproduces unjustifiable norms. I think we are in agreement here.

\section{The transcendental and the social self}

Marcus Düwell's work is a great example of a powerful reinterpretation of Kantian transcendental philosophy with important moral and political implications. Like myself, he takes the Kantian project seriously as a fundamental reflection on our status as autonomous persons endowed with a capacity for using reason. That capacity is itself normative in a specific sense, i.e., guided by principles of reason which, in practical contexts, have a moral import as to the question of the respect owed to autonomous persons. Thus we have no disagreement about Düwell's insistence that 'we must get some understanding of our own moral status as agents from the first-person perspective ${ }^{25}$ and that reflection on myself as an autonomous agent at the same time is a reflection on others as such agents worthy of respect. The only point where we might differ is in our interpretations and explanations of the phrase 'at the same time.' For unlike the philosophers in the idealist tradition, especially Fichte, I do not think that we should start from a subjective reflection on 'myself' first and then consider the status of others 'like me'; rather, I think that understanding myself in the right way already presupposes that I have understood that I am a member of a community of human beings connected through the practice of reason as reason-giving. I cannot give a full account of this here, as it goes not just beyond the scope of what I do in the rights paper but would also take too much space within a reply. So a few words might suffice. $^{26}$

Like Düwell, I am happy to provide a transcendental interpretation of what it means to be a 'judging being ${ }^{27}$ and to reconstruct the principles guiding the various contexts in which we form judgements, from the aesthetic to the moral and political. I would just add that forming judgments is a practice of justification and that if we take the practice of reason and reason-giving to be what it is, namely a practice of justification, then we can reflexively reconstruct the inner logic of certain practices of justification, from the ethical to the moral, legal or political, as I

Newey, 'The Justification of Basic Rights. A Response to Forst', 67.

Marcus Düwell, 'Frankfurt Goes Kantian - But How Does It Work?', Netherlands Journal of Legal Philosophy 45(3), 31.

For a full account, see the first two chapters of my The Right to Justification.

Düwell, Frankfurt Goes Kantian - But How Does It Work?', 34. 
do in Contexts of Justice, and we can give a transcendental account of the principles of justification that guide these practices and of the status of the agents of justification - us - as members of justification communities governed by certain norms of justification. The transcendental reflection reconstructs the conditions of the possibility of justifying certain beliefs, judgements or actions, and if we place it in the moral context that reflection allows us to see that we are the 'final' justificatory authorities when it comes to the validity of moral norms that claim to be reciprocally and generally justifiable. But we are not arbitrarily free in being such authorities, for we are bound to reason by being guided by the principle of justification and we are bound to each other by recognizing each other as equal normative authorities of justification. In the noumenal space of justifications, there is no special, higher authority apart from the principles of reason that we share in the discursive exercise of reasoning. As Kant says, reason has no dictatorial, only discursive, authority and its claim is never anything more than the agreement of free citizens, each of whom must be able to express his reservations, indeed even his veto, without holding back.' ${ }^{28}$

So my account proceeds in various steps, from the recursive reconstruction of the validity claims implicit in various contexts of justification to the transcendental reflection on the principles of reason and on us as normative authorities of reasonable justification. One can see here why I do not think that a transcendental reflection on our subjective self-understanding can proceed without at the same time analyzing the principles of justificatory reason or the membership in a justificatory community - in the case of morality the community of all moral persons. My reasoning connects practice and principle, self and society, in a way that avoids a primary focus on individual autonomy such that a second argument that generalizes such a self-understanding onto 'others' is required. A 'rational selfunderstanding ${ }^{29}$ is always already a social self-understanding, but one that reminds us of various memberships in real and in ideal justification communities. Justification is a practice of reason and a social practice, and I take my way of combining them to be superior to a Düwellian subject-focus that, despite his avowal to the contrary, sounds a bit 'solipsistic'30 to me.

Düwell also stresses that a determination of basic rights cannot simply be left to the determination by a political community, as there are important preconditions for participating in a normative order and for being an autonomous person in the first place. This is absolutely right, and I fear the criticism is based on a misunderstanding. I argue for basic rights for exactly the reasons that Düwell mentions. The moral construction argument for these rights as part of what I call 'fundamental justice' precisely says that there are demanding preconditions for being a political and social equal and non-dominated justificatory authority in the political realm and that it is the function of basic rights to secure that status, such that 
no others in 'factual agreement' 31 within a highly unequal society decide unfairly which rights and duties you have. This is the point of basic rights. So Düwell's first point about social disadvantage actually speaks for my argument and not against it - as I do not think that 'factual agreement' has any special authority if placed within a social structure of unequal justificatory power positions that question the status of justificatory equals. Düwell's second point about the universal scale of human rights is also important. ${ }^{32}$ I think the grave injustice consisting of one normative order dominating others is a central issue for a theory of transnational justice calling for transnational forms of democratic justification. ${ }^{33}$ So we agree here, too. And finally, when it comes to the question of inalienable rights, we agree, too, as I say in my critique of will-theories of rights. My whole argument is about the 'criteria by which to determine the content' of basic rights and I do not leave this to the arbitrary decisions of a collective. No Frankfurtstyle discourse theorist would, especially not me.

\section{Whose rights?}

Three of my commentators ask me about the limits of the community of rightsbearers according to my view. They are right to do this, as I do not say much in the paper about this important issue, hoping to be able to avoid thorny questions about membership in a normative order and who has which rights according to their degree of membership, from full citizenship on one end of the spectrum to being affected by the decisions and actions of a normative order as an outsider on the other. But these are not the questions Valentini, Newey, and Düwell focus on; rather, they ask me about the qualities of the persons that have basic rights. Valentini thinks that absent a theory of the interests that basic rights are supposed to protect or one about the capacities to be protected my account lacks an argument why I ascribe rights to all human beings 'independently of their capacities.' ${ }^{34}$ In her eyes, arguing as I do that any argument about the limits of the community of moral persons owed equal respect is necessarily a moral one and cannot be based on naturalistic or empirical grounds, is arguing for something 'mysterious and metaphysically dubious. ${ }^{35}$

I admit, however, that I find this mysterious in turn. For assume we were to say that we owe equal moral respect to beings who can feel pain or who have the capacity for reasoning. Are we then to infer that we can torture human beings who have lost the capacity to feel pain or who have lost their powers of reasoning? Or are we to infer that we have the duty to prevent animals to the best we

31 Düwell, Frankfurt Goes Kantian - But How Does It Work?', 37.

32 Düwell, Frankfurt Goes Kantian - But How Does It Work?', 37.

33 See Rainer Forst, 'Toward a Critical Theory of Transnational Justice,' in idem, Right to Justification, ch. 12; Rainer Forst, 'Transnational Justice and Democracy. Overcoming Three Dogmas of Political Theory,' in: Eva Erman and Sofia Näsström, eds., Political Equality in Transnational Democracy (New York: Palgrave Macmillan, 2013), ch. 3. 
can from suffering pain, including the pain they suffer from other animals? I find the first conclusion cruel and the second meaningless. Morality is a human institution, and there is no sufficient empirical basis or 'proof' for ascribing moral status to one being or the other; rather, it is a moral judgment based on our best account of whom we owe reasons to as justificatory equals even though they may not yet possess or have lost their justificatory powers. ${ }^{36}$ Especially in such moments, think of babies and the comatose or people with severe brain damage, we should understand that they depend on being treated by us on the basis of the best reasons we can give to anyone (to the moral community at large, which they are part of) about how to treat them. And with respect to animals, humanity as a moral institution obliges us to avoid cruel and 'inhumane' treatment of animals, but that is still an imperative by and for humans. I think it is a bad form of metaphysics to pretend that there is a non-moral basis for answering the question of the boundaries of the moral community, as if we could look at this from a divine, extra-human perspective.

Thus I agree with Düwell that the ascription of moral status cannot be "based on a biological property' ${ }^{37}$ and that we need an argument about the standing of foetuses, the comatose, or future people. There are no knock-down arguments here, just a reflection on what respect for others as justificatory beings means with respect to the foetus being part of the body of, another human being to whom we owe respect, the comatose still being a human person in the relevant moral sense, and future people standing in a relationship of dependency to us, though not existing at this time. We try to give the best account of what it means to treat others with dignity, i.e., as equal authorities in the normative realm to whom we owe reasons and respect. And that calls for special respect among humans that live together in one moral community, from birth to death, which does not mean that future persons do not count at all. But they are not yet fully part of the moral community. If we ask the question of the bounds of that community, we do that as part of that community, and that needs to be properly taken into account.

Thus while I agree with Newey that on some notions of the term 'person,' persons and human beings are not synonymous, I believe that those who have lost their cognitive powers are still moral persons, and they are also persons in many legal senses. They have not become mere objects. We need a moral philosophy that accounts for that status as a moral status and counts all humans as part of the moral community, knowing that any such determination is a moral reflection and not an empirically grounded one, which accounts best for the horrors human history has witnessed when one group of humans denied equal standing to others based on some arbitrary criterion of membership. Not distinguishing among humans with regard to moral membership in the community of respect is the best way to reflect on what it means to be an equal normative authority to others. You are obliged to use this authority to the best of your capacities, but if you lose

36 For a similar argument, see Thomas M. Scanlon, What We Owe to Each Other (Cambridge, MA: Harvard University Press, 1998), 184-86.

37 Düwell, Frankfurt Goes Kantian - But How Does It Work?', 38. 
these capacities, you do not lose membership in the moral community. That is why we call it a moral community, understanding that the term 'moral' is of an irreducibly moral nature.

I close with a final word of heartfelt thanks to my contributors for sharing that peculiar space of reasons that my paper has opened up with me and for asking me to enlarge and clarify it. I do not know whether I succeeded in doing so, but I at least learned a great deal about my own thinking in responding to their probing questions. I am greatly indebted to them for that. 


\section{SUMMARIES}

\section{The Justification of Basic Rights:} A Discourse-Theoretical Approach Rainer Forst

In this paper, I suggest a discourse theory of basic legal rights that is superior to rival approaches, such as a will-based or an interest-based theory of rights. Basic rights are reciprocally and generally justifiable and binding claims on others (agents or institutions) that they should do (or refrain from doing) certain things determined by the content of these rights. We call these rights basic because they define the status of persons as full members of a normative order in such a way that they provide protection from severe forms of legal, political and social domination. The very ground of these rights is the status of persons as free and equal normative authorities within the order they are subject to. In other words, these rights are grounded in a fundamental moral right to justification.

\section{Frankfurt Goes Kantian - But How Does It Work?}

\section{Marcus Düwell}

The paper discusses Forst's discourse- theoretical adaption of the Kantian heritage. If Forst sees a Kantian concept of human dignity as the basis of his approach, he cannot rely on Habermas' (quasi-)transcendental argument. It is furthermore questionable why Forst proposes that the content of human rights can only be determined in a procedural way. An alternative would be to determine the content from the normative starting point of human dignity.

\section{Two Sides of the Same Coin.}

\section{Unpacking Rainer Forst's Basic Right to Justification}

\section{Stefan Rummens}

This paper makes two comments on Rainer Forst's keynote contribution. It argues, first, that three important distinctions introduced by Forst are, in fact, all different versions of the more primary distinction between the a priori reconstruction of basic rights by philosophers and the discursive construction of basic rights by citizens. It proposes, secondly, an alternative discourse-theoretical reconstruction which makes a distinction between the basic right to justification and the basic right to choose your own ends as two different but inseparable rights - two sides of the same coin - which jointly provide the moral ground for our basic rights as citizens.

\section{On the Justification of Basic Rights}

\section{Laura Valentini}

In his thought-provoking article, Rainer Forst develops a discourse-theoretical approach to the justification of basic rights, and argues that it is superior to interestbased and autonomy-based views. I cast doubt on the superiority of the discoursetheoretical approach. I suggest that, on reflection, the approach suffers from the same difficulties that Forst believes undermine rival views. My discussion raises broader questions about what desiderata a good justification of basic rights should satisfy.

\section{The Justification of Basic Rights.}

\section{A Response to Forst}

\section{Glen Newey}

This paper responds to Rainer Forst's article 'The Justification of Basic Rights'. I argue that Forst's main thesis is difficult to pin down, partly because it is formulated in significantly distinct ways at numerous points. I offer a possible formulation of the argument but note that this encapsulates a fallacy; I further argue that his inference of the basic rights seems to imply an overmoralisation of social life and that his argument does not distinguish rights with discretionary and non-discretionary content. Then I query Forst's claim that a right to justification is a condition of engaging in justificatory discourse. This leads to the conclusion that what goes into the process of justification, including who figures in the discursive community, are irreducibly 
political questions, whose answers cannot be convincingly specified antecedently by a form of moral legislation. I argue that actual discursive processes allow for considerably more contingency and contextual variability than Forst's construction acknowledges. This extends, as I suggest in conclusion, to the idea that content can be specified via the Kantian notion that acceptability requires the 'containment' of an actor's ends by another, such as an affected party.

\section{What Does it Mean to Justify Basic Rights? Reply to Düwell, Newey, Rummens and Valentini}

Rainer Forst

In this paper, I reply to the four comments on my paper 'The Justification of Basic Rights: A Discourse-Theoretical Approach' given by Laura Valentini, Marcus Düwell, Stefan Rummens and Glen Newey. 


\section{AUTHOR INFORMATION}

Marcus Düwell is professor of Philosophical Ethics and director of the Ethics Institute, Utrecht University.

Rainer Forst is professor of Political Theory and Philosophy at the Goethe Universität, Frankfurt am Main.

Lisette ten Haaf is $\mathrm{PhD}$ candidate at the Department of Legal Theory and Legal History, Vrije Universiteit Amsterdam

Elaine Mak is professor of Jurisprudence at the Institute of Constitutional, Administrative Law and Legal Theory, Utrecht University

Glen Newey is professor of Political Philosophy and Ethics at Leiden University.

Stefan Rummens is professor of Moral Philosophy at the Institute of Philosophy of KU Leuven.

Laura Valentini is associate professor of Political Science at the London School of Economics and Political Science.

Bertjan Wolthuis is assistant professor at the Department of Legal Theory and Legal History, Vrije Universiteit Amsterdam 


\section{Boomjuridisch opleidingen}

\section{vebinars \\ video's \\ revents}

Van actualiteiten

tot diepgang

voor de juridische

professional 


\section{Introduction}

Bertjan Wolthuis, Elaine Mak \& Lisette ten Haaf,

Rainer Forst: The Justification of Basic Rights

\section{Articles}

Rainer Forst, The Justification of Basic Rights

A Discourse-Theoretical Approach

Marcus Düwell, Frankfurt Goes Kantian - But How

Does It Work?

Stefan Rummens, Two Sides of the Same Coin

Unpacking Rainer Forst's Basic Right to Justification

Laura Valentini, On the Justification of Basic Rights

Glen Newey, The Justification of Basic Rights

A Response to Forst

Rainer Forst, What Does it Mean to Justify Basic Rights?

Reply to Düwell, Newey, Rummens and Valentini 